\title{
Inoculation with mycorrhizal fungi on the growth and tolerance to water deficit of coffee plants
}

\author{
Samuel D. Moreira ${ }^{1}$, André C. França ${ }^{1}$, Wellington W. Rocha ${ }^{1}$, Evandro S. R. Tibães ${ }^{1} \&$ Eudes Neiva Júnior $^{1}$ \\ ${ }^{1}$ Universidade Federal dos Vales do Jequitinhonha e Mucuri/Campus JK/Departamento de Agronomia. Diamantina, MG. E-mail: agronomia_samuel@yahoo.com.br \\ (Corresponding author) - ORCID: 0000-0001-6385-5549; cabralfranca@yahoo.com.br - ORCID: 0000-0002-9009-3903; ww.willianr@yahoo.com.br - ORCID: 0000- \\ 0001-9550-8269; evandrotibaes@gmail.com - ORCID: 0000-0002-7410-2769; eudesneiva@hotmail.com - ORCID: 0000-0002-2826-867X
}

\section{Key words:}

Coffea arabica L.

Rubiaceae

field capacity

arbuscular mycorrhiza

\begin{abstract}
A B S T R A C T
Water stress can be alleviated in plants inoculated with arbuscular mycorrhizal fungi compared to that experienced by those without mycorrhizae. The objective of this study was to evaluate the growth of coffee plants colonized by arbuscular mycorrhizal fungi under different soil moisture conditions. Seeds of the coffee cultivar Catuaí Vermelho IAC 99 and three fungal inoculants (Rhizophagus clarus, Claroideoglomus etunicatum and Dentiscutata heterogama) were used in this study. The soil moisture contents tested were 40,60,80, and $100 \%$ of field capacity. Seedlings in the matchstick stage were inoculated with mycorrhizae, and then later planted in plastic pots when they developed four to five pairs of definitive leaves. Both the extent of mycorrhizal colonization and increases in leaf area were related to soil moisture content in a quadratic manner for plants inoculated with all three mycorhizzal fungi ( $R$. clarus, C. etunicatum, and D. heterogama), as well as for non-inoculated ones. The highest value of colonization of coffee by mycorrhizae was $39 \%$, which occurred in association with R. clarus at $71 \%$ of field capacity. The leaf areas of plants inoculated with fungi increased more than those of non-inoculated plants, regardless of the type of inoculum used. Plants inoculated with $D$. heterogama at $100 \%$ field capacity produced $21 \%$ more root dry mass than non-inoculated plants did. Inoculation with arbuscular mycorrhizal fungi and higher soil moisture increased the growth of coffee seedlings. The plants inoculated with $R$. clarus, $C$. etunicatum, and D. heterogama were tolerant to moderate water deficits (i.e. lower soil water contents). Mycorrhizal colonization was highest for plants in soils with moisture levels close to $75 \%$ of field capacity.
\end{abstract}

Palavras-chave:

Coffea arabica L.

Rubiaceae

capacidade de campo micorriza arbuscular

\section{Inoculação com fungos micorrízicos no crescimento e tolerância ao déficit hídrico em mudas de café}

\section{R E S U M O}

Plantas inoculadas com fungos micorrízicos arbusculares podem aliviar o estresse hídrico se comparadas às plantas não micorrizadas. Objetivou-se avaliar o crescimento do cafeeiro colonizado com fungos micorrízicos arbusculares em diferentes níveis de umidade do solo. Foram utilizadas sementes de café, cultivar Catuaí Vermelho IAC 99, e três inóculos de fungos: Rhizophagus clarus, Claroideoglomus etunicatum e Dentiscutata heterogama. As umidades do solo adotadas foram 40, 60, 80 e 100\% da capacidade de campo. Mudas no estádio palito de fósforo foram micorrizadas, e posteriormente plantadas, com quatro a cinco pares de folhas definitivas, em vasos plásticos. A colonização micorrízica e o incremento na área foliar das plantas inoculadas com $R$. clarus, C. etunicatum, $D$. heterogama e não inoculadas apresentaram comportamento quadrático. A maior colonização do cafeeiro foi $39 \%$ em associação com R. clarus, com $71 \%$ da capacidade de campo. As plantas inoculadas com fungo apresentaram maior incremento para área foliar do que as plantas não inoculadas, independentemente do inóculo utilizado. As plantas inoculadas com $D$. heterogama, na capacidade de campo $100 \%$, produziram $21 \%$ a mais de massa seca de raízes do que as não inoculadas. Os fungos micorrízicos arbusculares inoculados e o aumento da umidade do solo aumentaram o crescimento das mudas de café. As plantas inoculadas com $R$. clarus, C. etunicatum e D. heterogama foram tolerantes ao déficit hídrico moderado, suportando menor quantidade de água no solo. A colonização micorrízica foi maior em solos com umidade próxima a 75\% da capacidade de campo. 


\section{INTRODUCTION}

Coffee (Coffea arabica L.) cultivation is one of the most important activities of the agricultural sector in Brazil (Carvalho et al., 2017). Its success is limited there, however by high temperatures and irregular rainfall, and great losses have occurred due to the increasing frequency of "Veranico" (little summers) in recent years (Dominghetti et al., 2014).

Irrigation allows coffee plants to be cultivated even in limiting situations, such as when rainfall is scarce (Dominghetti et al., 2014). This technology is necessary during drought events to meet the water requirements of coffee plants, which is needed to stimulate plant development, increase production, and obtain a quality beverage product from coffee seeds (Silva et al., 2011).

In the absence of irrigation, the water stress experienced by plants inoculated with arbuscular mycorrhizal fungi (AMF) can be alleviated compared to that experienced by non-inoculated plants (Ruiz-Lozano et al., 2016); this may constitute an alternative method that can be used to minimize the effects of water deficits on crops. In association with host plant roots, AMF form arbuscular mycorrhizae (AM), which improve the host plant's ability to absorb nutrients and water from the soil (Santander et al., 2017).

The AM association increases plant tolerance to drought and other environmental stressors, such as high heavy metals concentrations, salinities, and temperatures (Andrade et al., 2009). The presence of AMF also influences soil structure because the mechanical actions of fungal hyphae induce particle aggregation, and the fungi themselves excrete glycoproteins and other extracellular compounds that impact soil composition (Andrade et al., 2009).

Arbuscular mycorrhizae are found naturally in coffee plantations (Posada et al., 2018). Particular AMF could be selected for intentional use in coffee cultivation to enrich the coffee plants' rhizosphere, so that the benefits of this symbiosis can be taken advantage of by the coffee cultivation industry (França et al., 2014; Suparno et al., 2015).

Therefore, the objective of the present study was to evaluate the growth of coffee plants colonized with arbuscular mycorrhizal fungi under conditions of different soil moisture contents.

\section{Material AND Methods}

The experiment performed in this study was conducted between August 2012 and November 2013 in a greenhouse located at the Federal University of Jequitinhonha and Mucuri Valleys, Diamantina, MG, Brazil (18 $12^{\prime} 12^{\prime \prime}$ S, 43 34' 16" W, altitude $1403 \mathrm{~m}$ ).
In the experiment, coffee (Coffea arabica) seeds of the Catuaí Vermelho IAC 99 cultivar, and three different arbuscular mycorrhizal fungal (AMF) inocula were used: Rhizophagus clarus (RJN102A), Claroideoglomus etunicatum (RJN101A), and Dentiscutata heterogama (PNB102A). AMF inocula were obtained from the International Glomeromycota Culture Collection (CICG).

The spore densities in AMF inocula were quantified using a wet sieving technique, followed by centrifugation in water for $3 \mathrm{~min}$ at $3000 \mathrm{rpm}$ and then in 50\% sucrose for $2 \mathrm{~min}$ at 2000 rpm (Gerdemann \& Nicolson, 1963). Spores were subsequently counted under a magnifying glass.

Coffee seeds were sown in washed sand, and were then transplanted in August 2012, when they had reached the "matchstick" stage but before the release of the hypocotyl leaf. Seedlings were inoculated at the time of transplanting, when they were placed into polyethylene bags containing $1.6 \mathrm{dm}^{3}$ of soil plus one of the three respective fungi inocula. The amount of inoculum added, which comprised sand, expanded clay, and root fragments, was sufficient to provide 100 spores to each seedling. Control seedlings were also raised that did not receive any type of inoculum.

The soil used for plant growth consisted of a dystrophic RedYellow Latosol (surface horizon 0-20 cm), sieved through a 4-mm mesh. Soil analysis was performed according to the methodology proposed by EMBRAPA (1997) (Table 1). The soil contained a density of 14 native fungal spores per gram of soil. Fertilization was carried out according to the methods of Guimarães et al. (1999), except for the use of phosphate fertilizers.

The seedling phase occurred between October 2012 and May 2013. Plants were ready for replanting as seedlings after they exhibited four to five pairs of definitive leaves (ca. 150 days after transplanting).

The experiment consisted of a randomized complete block design, with four replicates arranged in a $4 \mathrm{x} 4$ factorial scheme consisting of coffee seedlings either non-inoculated (control) or inoculated with R. clarus, C. etunicatum, or D. heterogama, at each of four different soil moisture contents.

The soil moisture contents tested were $40,60,80$, and $100 \%$ of field capacity (FC), corresponding to $0.1526,0.2287,0.3001$, and $0.3812 \mathrm{~cm}^{3}$ of water per $\mathrm{cm}^{3}$ of soil, respectively. The field capacity was determined by the Richards pressure chamber method, with five soil samples (Table 1 ) subjected to this assay (EMBRAPA, 2005) at a pressure of $6 \mathrm{kPa}$.

Seedlings were planted in plastic pots containing $18 \mathrm{dm}^{3}$ of the same soil they had been growing in previously, plus $0.74 \mathrm{~g} \mathrm{~kg}^{-1}$ of $\mathrm{P}_{2} \mathrm{O}_{5}$. The amount of phosphate fertilization applied was $50 \%$ of that recommended by Guimarães et al. (1999). Each experimental unit consisted of one plant in one pot.

Table 1. Characteristics of the dystrophic Red-Yellow Latosol used for coffee cultivation in the study before fertilization and acidity correction

\begin{tabular}{|c|c|c|c|c|c|c|c|c|c|}
\hline \multirow{2}{*}{$\mathrm{pH}\left(\mathrm{H}_{2} \mathrm{O}\right)$} & $\mathbf{P}$ & $\mathrm{K}$ & $\mathrm{Ca}^{2+}$ & $\mathrm{Mg}^{2+}$ & $\mathrm{Al}^{3+}$ & $\mathrm{H}+\mathrm{Al}$ & $\mathrm{T}$ & $t$ & $0 . \mathrm{M}$ \\
\hline & \multicolumn{2}{|c|}{$\left(\mathrm{mg} \mathrm{dm}^{-3}\right)$} & \multicolumn{6}{|c|}{$\left(\mathrm{cmol}_{\mathrm{G}} \mathrm{dm}^{-3}\right)$} & $\left(\right.$ dag $\left.\mathrm{kg}^{-1}\right)$ \\
\hline 4.9 & 1.3 & 8 & 0.1 & 0.1 & 0.3 & 46 & 4.9 & 0.6 & 1.9 \\
\hline \multirow{2}{*}{$\begin{array}{l}\text { P-rem } \\
\mathrm{mg} \mathrm{L}^{-1}\end{array}$} & $\mathrm{Zn}$ & $\mathrm{Fe}$ & $M n$ & $\mathrm{Cu}$ & B & & Sand & Silt & Clay \\
\hline & \multicolumn{5}{|c|}{$\left(\mathrm{mg} \mathrm{dm}^{-3}\right)$} & & \multicolumn{3}{|c|}{$\left(g^{k g}{ }^{-1}\right)$} \\
\hline 7.1 & 0.2 & 30.5 & 0.7 & 0.1 & 0.1 & & 380 & 80 & 560 \\
\hline
\end{tabular}

0.M. - Organic matter; T - Cation exchange capacity at pH 7.0; $\mathrm{t}$ - Effective cation exchange capacity 
On the day of planting, the leaf area of the seedlings was determined using the non-destructive method proposed by Antunes et al. (2008). Plants were kept at $80 \%$ field capacity for 30 days after planting, after which the application of different water content treatments was started. Soil moisture control and monitoring were carried out using an electronic soil moisture meter (Hidrofarm - model HFM2030), with each experimental unit evaluated every two days until it reached the target moisture content for each treatment.

At 150 days after planting (DAP), the leaf area was evaluated once more. The leaf area increment was determined by subtracting the value obtained on the first day of planting from that measured at 150 DAP. Total chlorophyll indices were also measured on the same day for four leaves originating from the middle third of each plant's stem using an electronic chlorophyll content meter (chlorofilOG - CFL1030). Subsequently, chlorophyll content was calculated indirectly from measurements of the SPAD index according to the methods of Porra et al. (1989), adapting the following equation: $\mathrm{Yt}=2.1468+0.1022 \mathrm{x}+0.002 \mathrm{x}^{2}\left(\mathrm{R}^{2}=0.91\right)$, in which $\mathrm{x}=$ the SPAD index value and $\mathrm{Yt}=$ total chlorophyll.

At 150 DAP, coffee plants were removed from the pots, divided up into leaves, stems and roots, and then the dry mass of each plant part was determined after drying them in
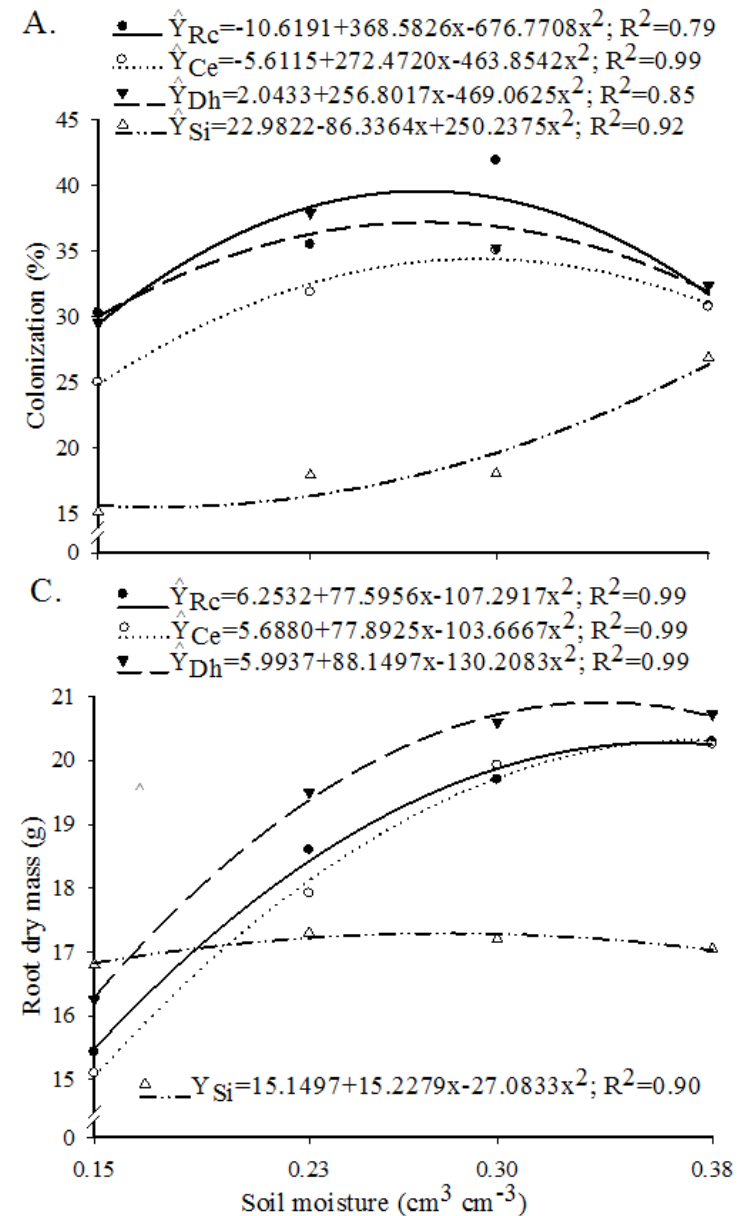

Figure 1. Percentage of root lengths colonized by fungi (colonization) (A), increase in leaf area (B), root dry mass (C), and aerial part/root ratio (AP/R) (D) of coffee plants inoculated with Rhizophagus clarus (Rc), Claroideoglomus etunicatum (Ce), or Dentiscutata heterogama (Dh), or without inoculation (Si), at soil water contents of $0.15,0.23,0.30$, and $0.38 \mathrm{~cm}^{3}$ of water per $\mathrm{cm}^{3}$ of soil, corresponding to $40,60,80$, and $100 \%$ of the soil field capacity, respectively a forced air circulation oven at $65^{\circ} \mathrm{C}$ until a constant weight was reached. The aerial part/roots ratio $(\mathrm{AP} / \mathrm{R})$ was calculated based on these dry masses.

The percentage of root length colonized by AMF (percentage of colonization) was calculated from samples of the root system. These samples (approximately $1 \mathrm{~g}$ of roots) were taken from each experimental unit and stored in a 1:1:18 solution of formaldehyde: acetic acid: $96 \%$ ethanol.

Root samples were cleaned with $10 \% \mathrm{KOH}$, acidified with $1 \% \mathrm{HCl}$, and stained with trypan blue in $0.05 \%$ lactoglycerol (Phillips \& Hayman, 1970). Mycorrhizal colonization was then evaluated by the intersection method in a counting chamber under a stereoscopic microscope (Giovannetti \& Mosse, 1980), in which at least 100 root segments were counted.

Data were compared among treatments using analysis of variance, performed by means of the F-test ( $\mathrm{p} \leq 0.05$ ), in which significant interactions were decomposed by performing regression analyses of the relationship between the different soil moisture contents and the dependent variables examined.

\section{Results AND Discussion}

Mycorrhizal colonization of plants inoculated with $R$. clarus, C. etunicatum, and D. heterogama was higher than that of non-inoculated specimens (Figure 1A). The latter plants
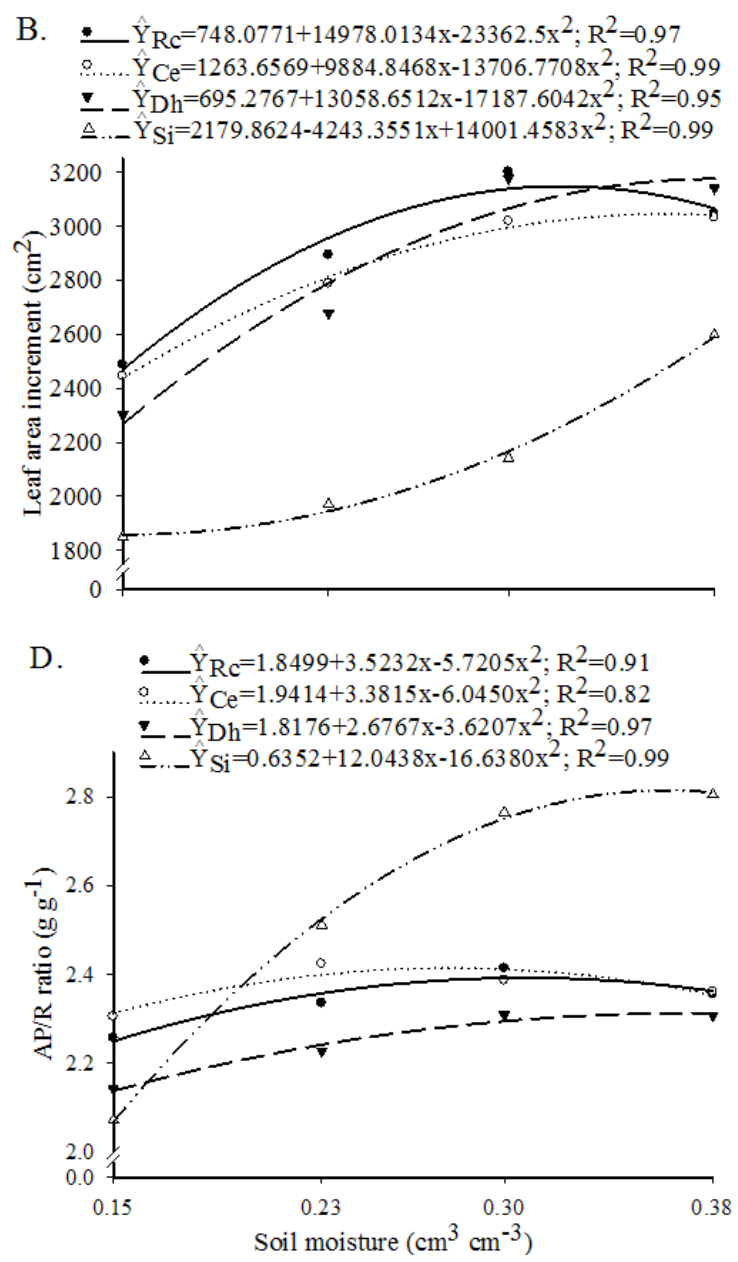
were still colonized by AMF since natural soil, which contained native fungal spores, was used. Thus, it is worth mentioning that the efficiency of the selected AMF used in this study in colonizing coffee plants was much higher than that of native AMF in the soil.

The highest percent root colonization was achieved by C. etunicatum at a $0.29 \mathrm{~cm}^{3} \mathrm{~cm}^{-3}$ soil moisture content $(76 \%$ of field capacity), whereas $R$. clarus and D. heterogama both reached their peak colonization percentage values at $0.27 \mathrm{~cm}^{3} \mathrm{~cm}^{-3}$ (71\% of field capacity) (Figure 1A). The highest percent coffee colonization achieved was $39 \%$, which occurred in plants inoculated with $R$. clarus in soils at $71 \%$ of field capacity.

The decrease in AMF colonization observed under a soil water content of $0.38 \mathrm{~cm}^{3} \mathrm{~cm}^{-3}$ (100\% of field capacity) may have been due to the increased presence of parasites or decreased aeration caused by the water content in the soil being too high. Soils with a very high moisture content suffer from a lack of oxygen that decreases the activity of aerobic AMF and thus can negatively impact plants (Moreira \& Siqueira, 2006).

Higher moisture contents also favor the development of parasites of AMF fungal spores. Microorganisms present in the soil may exert an inhibitory effect on spore germination and fungal mycelial growth by acting as predators or parasites of fungi, or as producers of fungistatic substances (Moreira \& Siqueira, 2006).

Even in the presence of native fungi, the inoculated AMF were able to colonize coffee plants after they were replanted in pots containing natural soil. This indicates the efficiency of these fungi, even in a competitive setting, to promote coffee plant growth up to 150 DAP. The different AMF inocula caused different responses in the variables analyzed, although the effects of $R$. clarus and C. etunicatum differed very little from one another.

The greatest increase in the leaf area of plants inoculated with $D$. heterogama, C. etunicatum, and $R$. clarus occurred at moisture contents of $0.38,0.36$, and $0.32 \mathrm{~cm}^{3} \mathrm{~cm}^{-3}$, respectively (Figure 1B). The leaf area of non-inoculated plants increased by the greatest amount when the soil was at $100 \%$ field capacity, which represented a $40 \%$ increase in leaf area compared to that of plants in soil with the lowest moisture content tested.

Leaf area increased more in AMF-inoculated plants than in non-inoculated plants, particularly at the lowest soil moisture content tested, where leaf area was increased by $20 \%$ with AMF inoculation. Due to their better performance under water stress, coffee plants inoculated with AMF would likely tolerate drought better than non-inoculated ones.

Several studies have demonstrated increased drought tolerance in mycorrhized plants, including maize (Quiroga et al., 2017), sunflower (Gholamhoseini et al., 2013), and tomato (Chitarra et al., 2016). The formation of AM may increase soil stability (Gianinazzi et al., 2010) through the particleaggregating effects of the mechanical actions of fungal hyphae and their excretion of glycoproteins and other extracellular compounds (Andrade et al., 2009), which help maintain soil moisture for longer periods of time.

The root dry mass of non-inoculated plants did not change with increasing soil moisture (Figure 1C). For AMF-inoculated plants, the root dry mass was only lower than that of noninoculated plants at $0.15 \mathrm{~cm}^{3} \mathrm{~cm}^{-3}$ soil moisture content.
From this point onwards, increases in soil moisture yielded higher root dry masses in inoculated plants compared to noninoculated specimens.

The tolerance of mycorrhized coffee plants to water deficits may be related to the plants' physiological mechanisms. Stomata control gas exchange between the internal leaf environment and the external environment. In plants with AM associations, stomatal behavior is usually altered, which influences the hydration, carbon sequestration, photosynthesis, and biomass accumulation of the plant (Augé et al., 2015).

Inoculation with $D$. heterogama yielded a $21 \%$ increase in root dry mass over that of non-inoculated plants at $0.38 \mathrm{~cm}^{3} \mathrm{~cm}^{-3}$ soil moisture content. Similar results were found for plants inoculated with $R$. clarus and C. etunicatum at increasing soil moisture levels (Figure 1C).

The AP/R ratio showed little variation among soil moisture levels for AMF-inoculated plants (Figure 1D). This indicates that the inoculated plants were able to maintain their growth even in soils suffering from water deficits. Consequently, a moderate water deficit did not compromise the dry matter production of the aerial parts of plants because the AMF guaranteed that the root system's reserves would be able to contribute to the growth of the aerial parts. Mycorrhized plants showed higher AP/RS ratios than non-inoculated ones, indicating that they had a more well-developed root system, with more branches and a better distribution throughout the soil (Saggin Júnior \& Silva, 2005).

In conditions of water stress, plants with AM exhibit more growth and a better physiological state, including photosynthetic rate, stomatal conductance, and water use efficiency, compared to non-mycorrhized plants (Xie et al., 2018). Some mechanisms that may explain this relief from water stress conditions by AM may include the alteration of abscisic acid levels and regulation of stress-responsive genes (Chitarra et al., 2016; Ruiz-Lozano et al., 2016).

The total chlorophyll content, leaf dry mass, stem dry mass, and total dry mass exhibited a quadratic relationship with soil moisture content, in which they initially increased with increasing soil moisture but then stabilized or declined at higher moisture contents (Figure 2).

The chlorophyll and total dry mass contents of coffee plants were highest at $0.35 \mathrm{~cm}^{3} \mathrm{~cm}^{-3}$ soil moisture conditions (Figures $2 \mathrm{~A}, \mathrm{D})$. The largest leaf dry mass value was observed at $0.34 \mathrm{~cm}^{3} \mathrm{~cm}^{-3}$ (Figure $2 \mathrm{~B}$ ), whereas the dry stem mass was highest at a $0.36 \mathrm{~cm}^{3} \mathrm{~cm}^{-3}$ soil moisture content (Figure $2 \mathrm{C}$ ); all of these levels at which maximum values occurred were close to the soil field capacity.

All results of the present study, especially those that showed only soil moisture effects (Figure 2), show that the low volume of water present in the soil under water deficit (i.e. drought) conditions compromises the growth of coffee plants, since the lack of water directly or indirectly affects many cellular physiological processes in plants (Marenco \& Lopes, 2005).

Plants under conditions of low soil moisture close their stomata, since otherwise transpiration would exceeds the uptake of water by the roots; however, this restricts $\mathrm{CO}_{2}$ entry into the plant, and thereby reduces the amount of photosynthesis performed. Water stress also influences the structural and functional development of chloroplasts, and 

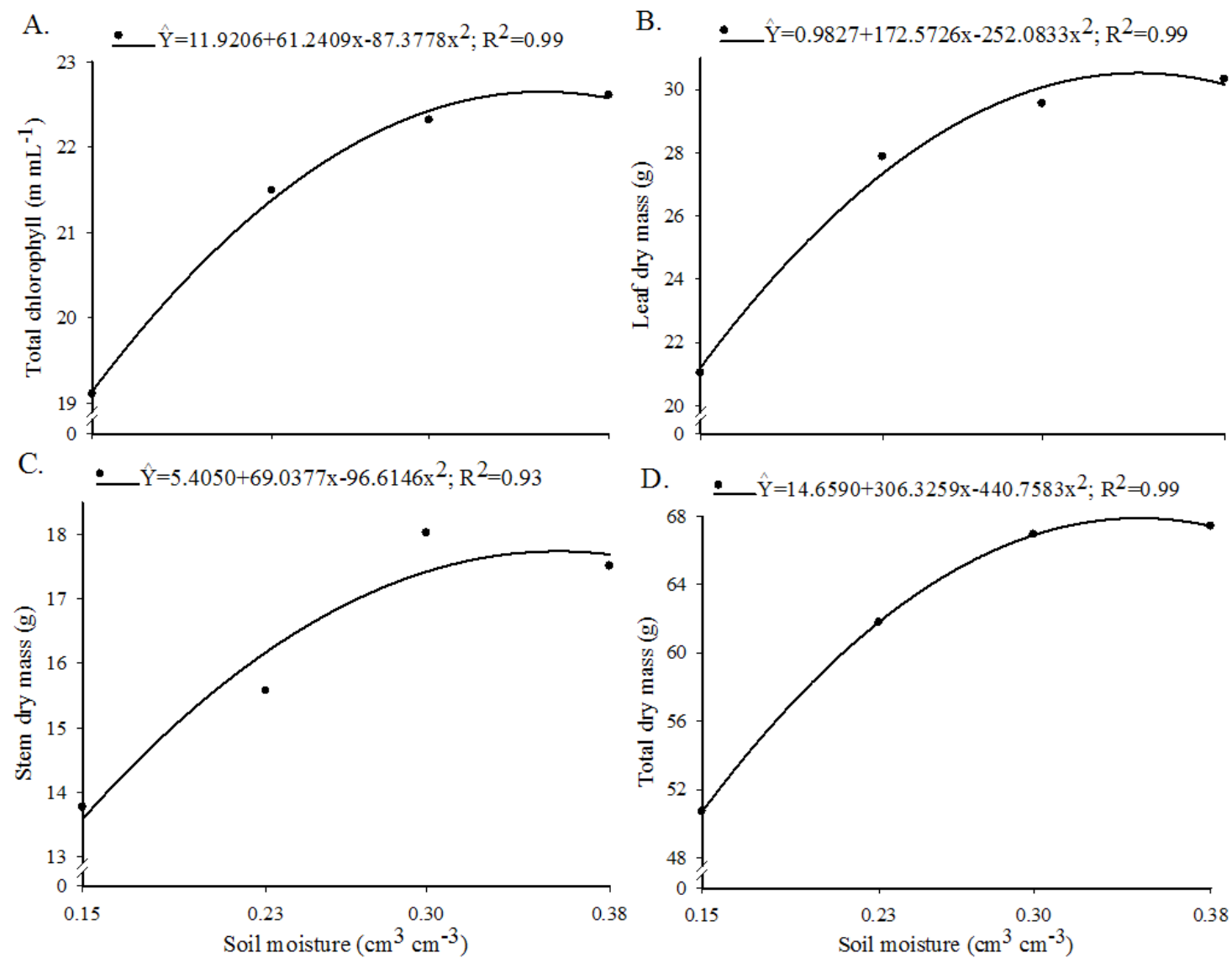

Figure 2. Total chlorophyll content (A), leaf dry mass (B), stem dry mass (C), and total dry mass (D) of non-inoculated and Rhizophagus clarus-, Claroideoglomus etunicatum-, and Dentiscutata heterogama-inoculated coffee plants grown under $0.15,0.23,0.30$, and $0.38 \mathrm{~cm}^{3} \mathrm{~cm}^{-3}$ soil moisture contents, corresponding to $40,60,80$, and $100 \%$ of the soil field capacity, respectively

chlorophyll synthesis. In this situation, water stress accelerates chlorophyll degradation and reduces the rate of its synthesis (Marenco \& Lopes, 2005).

\section{Conclusions}

1. Inoculation with arbuscular mycorrhizal fungi and soil moisture contents up to $75 \%$ of field capacity increased the growth of coffee plants.

2. Mycorrhizal colonization was highest in soils with water contents close to $75 \%$ of field capacity.

3. Plants inoculated with Rhizophagus clarus, Claroideoglomus etunicatum, and Dentiscutata heterogama were tolerant to water stress (i.e. conditions of up to $40 \%$ of field capacity) in a RedYellow Latosol.

\section{ACKNowledgements}

Thanks are given to CNPq, CAPES, and FAPEMIG, for financial support provided to conduct this study.

\section{Literature Cited}

Andrade, S. A.; Mazzafera, L. P.; Schiavinato, M. A.; Silveira, A. P. D. Arbuscular mycorrhizal association in coffee. Journal of Agricultural Science, v.147, p.105-115, 2009. https://dx.doi. org/10.1017/S0021859608008344
Antunes, W. C.; Pompelli, M. F.; Carretero, D. M.; Damatta, F. M. Allometric models for non-destructive leaf area estimation in coffee (Coffea arabica and Coffea canephora). Annals of Applied Biology, v.153, p.33-40, 2008. https://dx.doi.org/10.1111/j.17447348.2008.00235.x

Augé, R. M.; Toler, H. D.; Saxton, A. M. Arbuscular mycorrhizal symbiosis alters stomatal conductance of host plants more under drought than under amply watered conditions: A meta-analysis. Mycorrhiza, v.25, p.13-24, 2015. https://doi.org/10.1007/ s00572014-0585-4

Carvalho, L. C. C.; Silva, F. M. da; Ferraz, G. A. e S.; Stracieri, J.; Ferraz, P. F. P.; Ambrosano, L. Geostatistical analysis of Arabic coffee yield in two crop seasons. Revista Brasileira de Engenharia Agrícola e Ambiental, v.21, p.410-414, 2017. http://dx.doi.org/10.1590/18071929/agriambi.v21n6p410-414

Chitarra, W.; Pagliarani, C.; Maserti, B.; Lumini, E.; Siciliano, I.; Cascone, P.; Schubert, A.; Gambino, G.; Balestrini, R.; Guerrieri, E. Insights on the impact of arbuscular mycorrhizal symbiosis on tomato tolerance to water stress. Plant Physiology, v.171, p.10091023, 2016. https://dx.doi.org/10.1104/pp.16.00307

Dominghetti, A. W.; Scalco, M. S.; Guimarães, R. J.; Silva, D. R. G.; Carvalho, J. P. S.; Pereira, V. A. Doses de fósforo e irrigação na nutrição foliar do cafeeiro. Revista Brasileira de Engenharia Agrícola e Ambiental, v.18, p.1235-1240, 2014. http://dx.doi. org/10.1590/1807-1929/agriambi.v18n12p1235-1240

EMBRAPA - Empresa Brasileira de Pesquisa Agropecuária. Manual de métodos de análises de solo. 2.ed. Rio de Janeiro: Embrapa Solos, 1997. 212p. 
EMBRAPA - Empresa Brasileira de Pesquisa Agropecuária. Manual de laboratórios: Solo, água, nutrição vegetal, nutrição animal e alimentos. São Carlos: Embrapa Pecuária Sudeste, 2005. 334p.

França, A. C.; Carvalho, F. P.; Franco, M. H.; Avelar, M.; Souza, B. P.; Stürmer, S. L. Crescimento de mudas de cafeeiro inoculadas com fungos micorrízicos arbusculares. Revista Brasileira de Ciências Agrárias, v.9, p.506-511, 2014. https://doi.org/10.5039/agraria. v9i4a3938

Gerdemann, J. W.; Nicolson, T. H. Spores of mycorrhizal endogone species extracted from soil by wet sieving and decanting. Transactions of the British Mycological Society, v.46, p.235-244, 1963. https://doi.org/10.1016/S0007-1536(63)80079-0

Gholamhoseini, M.; Ghalavand, A.; Dolatabadian, A.; Jamshidi, E.; Khodaei-Joghan A. Effects of arbuscular mycorrhizal inoculation on growth, yield, nutrient uptake and irrigation water productivity of sunflowers grown under drought stress. Agricultural Water Management, v.117, p.106-114, 2013. https://doi.org/10.1016/j. agwat.2012.11.007

Gianinazzi, S.; Gollotte, A.; Binet, M. N.; Tuinen, D. van; Redecker, D.; Wipf, D. Agroecology: The key role of arbuscular mycorrhizas in ecosystem services. Mycorrhiza, v.20, p.519-530, 2010. https:// doi.org/10.1007/s00572-010-0333-3

Giovannetti, M.; Mosse, B. An evaluation of techniques for measuring vesicular-arbuscular mycorrhizal infection in roots. New Phytologist, v.84, p.489-500, 1980. https://doi.org/10.1111/j.1469-8137.1980. tb04556.x

Guimarães, P. T. G.; Garcia, A. W. R.; Alvarez V., V. H.; Prezotti, L.C.; Viana, A. S.; Miguel, A. E.; Malavolta, E.; Corrêa, J. B.; Lopes, A. S.; Nogueira, F. D.; Monteiro, A. V. C. Cafeeiro. In: Ribeiro, A. C.; Guimarães, P. T. G.; Alvarez V., V. H. (ed.). Recomendação para o uso de corretivos e fertilizantes em Minas Gerais. 5.aprox. Viçosa: Comissão de Fertilidade do Solo do Estado de Minas Gerais, 1999. p.289-302.

Marenco, R. A.; Lopes, N. F. Fisiologia vegetal: Fotossíntese, respiração, relações hídricas e nutrição mineral. Viçosa: Editora UFV, 2005. 451p.

Moreira, F. M. de S.; Siqueira, J. O. Microbiologia e bioquímica do solo. 2.ed. Lavras: Editora UFLA, 2006. 729p.

Phillips, J. M.; Hayman, D. S. Improved procedures for clearing roots and staining parasitic and vesicular-arbuscular mycorrhizal for rapid assessment of infection. Transactions of the British Mycological Society, v.55, p.158-161, 1970. https://doi.org/10.1016/ S0007-1536(70)80110-3
Porra, R. J.; Thompson, W. A.; Kriedermann, P. E. Determination of accurate extinction coefficients and simultaneous equation for assaying chlorophylls and b extracted with four different solvents: Verification of the concentration of chlorophylls standards by atomic absorption spectroscopy. Biochimica et Biophysica Acta, v.975, p.384-394, 1989. https://doi.org/10.1016/S0005-2728(89)80347-0

Posada, R. H.; Prager, M. S. de; Heredia-Abarca, G.; Sieverding, E. Effects of soil physical and chemical parameters, and farm management practices on arbuscular mycorrhizal fungi communities and diversities in coffee plantations in Colombia and Mexico. Agroforestry Systems, v.92, p.555-574, 2018. https:// doi.org/10.1007/s10457-016-0030-0

Quiroga, G.; Erice, G.; Aroca, R.; Chaumont, F.; Ruiz-Lozano, J. M. Enhanced drought stress tolerance by the arbuscular mycorrhizal symbiosis in a drought-sensitive maize cultivar is related to a broader and differential regulation of host plant aquaporins than in a drought-tolerant cultivar. Frontiers in Plant Science, v.8, p.115, 2017. https://doi.org/10.3389/fpls.2017.01056

Ruiz-Lozano, J. M.; Aroca, R.; Zamarreño, Á. M.; Molina, S.; AndreoJiménez, B.; Porcel, R.; García-Mina, J. M.; Ruyter-Spira, C.; López-Ráez, J. A. Arbuscular mycorrhizal symbiosis induces strigolactone biosynthesis under drought and improves drought tolerance in lettuce and tomato. Plant, Cell and Environment, v.39, p.441-452, 2016. https://doi.org/10.1111/pce.12631

Saggin Júnior, O. J.; Silva, E. M. R. da. Micorriza arbuscular: Papel, funcionamento e aplicação da simbiose. In: Aquino, A. M. de; Assis, R. L. de (eds.). Processos biológicos no sistema solo-planta: Ferramentas para uma agricultura sustentável. Brasília: Embrapa Informação Tecnológica, 2005. p.101-149.

Santander, C.; Aroca, R.; Ruiz-Lozano, J. M.; Olave, J.; Cartes, P.; Borie, F.; Cornejo, P. Arbuscular mycorrhiza effects on plant performance under osmotic stress. Mycorrhiza, v.27, p.639-657, 2017. https:// dx.doi.org/10.1007/s00572-017-0784-x

Silva, A. C. da; Lima, L. A.; Evangelista, A. W. P.; Martins, C. P. Evapotranspiração e coeficiente de cultura do cafeeiro irrigado por pivô central. Revista Brasileira de Engenharia Agrícola e Ambiental, v.15, p. 1215-1221, 2011. http://dx.doi.org/10.1590/ S1415-43662011001200001

Suparno, A.; Prabawardani, S.; Yahya, S.; Taroreh, N. A. Inoculation of arbuscular mycorrhizal fungi increase the growth of cocoa and coffee seedling applied with Ayamaru Phosphate Rock. Journal of Agricultural Science, v.7, p.199-210, 2015. http://dx.doi. org/10.5539/jas.v7n5p199

Xie, W.; Hao, Z.; Zhou, X.; Jiang, X.; Xu, L.; Wu, S.; Zhao, A.; Zhang, X.; Chen, B. Arbuscular mycorrhiza facilitates the accumulation of glycyrrhizin and liquiritin in Glycyrrhiza uralensis under drought stress. Mycorrhiza, v.28, p.285-300, 2018. https://doi.org/10.1007/ s00572-018-0827-y 